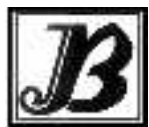

J. bio-sci. 21: 141-144, 2013

ISSN 1023-8654

http://www.banglajol.info/index.php/JBS/index

- Short Communication

\title{
FOOD AND FEEDING HABITS OF JUVENILE WHITE SEA BASS, LATES CALCARIFER (BLOCH) FROM THE SHIBSHA RIVER IN THE SOUTH-WESTERN COASTAL REGION OF BANGLADESH
}

\author{
Sk. Kamruzzaman, Syeda Mushahida-Al-Noor*, Md. Delwer Hossain
}

Department of Fisheries, Faculty of Agriculture, University of Rajshahi, Rajshahi 6205, Bangladesh

Lates calcarifer (Bloch) is a brackish water fish and commonly known as "Barramundi". It is also famous by the name of Cock-up sea perch. It is locally called as "Coral" in Bangladesh. L. calcarifer is a commercially important euryhaline fish of the Indian sub-continent and it grows to a comparatively large size with delicate, flovoured flesh and commands high price in the markets (Das 2000). Barramundi are valuable both as recreational and commercial fish, with a high, fairly stable price (Luna 2008). It has become a vulnerable in marine species due to over exploitation (Cheung et. al. 2005). It is available in seas and estuaries of India, Ceylon and Bangladesh to throughout most of the Northern part of the Eastern Indian Ocean, western central pacific area and south ward to northern coasts of Australia, also westward to Karachi (Fishcher et al. 1974). Some other reports stated the evidence of $L$. calcarifer in Bangladesh (Rahman 1989), India (Kapoor et al. 2002), Pakistan (Bianchi 1985), Sri-lanka (Pethiyagoda 1991), Thailand (Yadav 1999) and East Africa (Kungvankij et al. 1986) have been found.

L. calcarifer is a diadromous species (Kungvankij et al. 1986), inhabiting rivers before returning to the estuaries to spawn. Larvae and young juveniles live in brackish temporary swamps associated with estuaries, and older juveniles inhabit the upper reaches of rivers (Allen et al. 2002). Some common habitats of $L$. calcerifer are the Bay of Bengal, commonly found in estuaries of Barishal, Patuakhali and Khulna of the south-western coastal region of Bangladesh (Rahman 1989).

Few previous studies like De (1971), Davis (1985), Tacon et al. (1991), Kailasam et. al. (2002) and Patnaik et al. (2011) studied food and feeding habit of Lates calcarifer around the world. But at present, no published information is available on the food, feeding habits and related length-length relationship of this commercially important fish from Shibsha River of Bangladesh. The results of the food and feeding study would be useful in future for stocking, successful farming and management of this species in impounded water bodies.

Specimens of $L$. calcarifer were collected from the Shibsha river by commercial gill net or triangular net or cast net, commonly used in the south-western part of Bangladesh (Latitude $20^{\circ} 25^{\prime} \mathrm{N}$; Longitude $89^{\circ} 20^{\prime} \mathrm{E}$ ). The Shibsha river is believed to be an important spawning and feeding ground for marine fish species of south-western coastal region of Bangladesh. L. calcarifer specimens were collected monthly from the sampling site (Khulna area) in the Shibsha river during day time (11:00-17:00 hours) from June, 2010 to July, 2011 by means of traditional gill nets. Specimens were preserved in $10 \%$ buffered formalin, packed in wooden boxes and transported to the laboratory of Fish Biology, Department of Fisheries, University of Rajshahi, Bangladesh. 
A total of 680 fish measuring $15.4-25.0 \mathrm{~cm}$ total length (TL) were examined. Standard length (SL) was measured with a slide caliper to the nearest $0.01 \mathrm{~cm}$. Alimentary canal length Fish were opened was recorded after opening the abdomen. The degree of stomach fullness was assessed according to the subjective scale described by Gravimetric method (Hynes 1950 and Pillay 1954). The data were then used to calculate the monthly Fullness Index (FI).

$\mathrm{FI}(\%)=\frac{\text { Number of stomachs with the same degree of fullness }}{\text { Total number of stomachs examined }} \times 100$

The gut was then excised, weighed (g) together with its contents and preserved in $70 \%$ alcohol. Subsequently, stomach contents were suspended in water in Petri dishes and undigested prey were identified to the possible taxon using the identification keys of Todd and Laverack (1991) and Needham \& Needham (1962). The contribution of each food type to the diet and the frequency of occurrence were determined according to Hynes (1950). The proportion of total prey items contributed by each prey group for the entire year was determined according to the numerical method (Bowen, 1985). Mathematical relationship between the total length $(T L)$ of the fish and the alimentary canal length $(A C L)$ of juvenile was established by regression equation, $y=a+b x$ was followed where $y$ is Alimentary canal length $(A C L), x$ is Total length $(T L)$, $a$ is the interception on the ordinate and $b$ is the regression co-efficient.

The proportion of total food items contributed to each items for the entire year shows that the major component of the diet was teleostei were dominant (33.70\%). Among the teleostei, Apocryptes, Jonieops, Otolithoides, Harpodon, Coilia, Polynemus, Pama, Therapon, Chanda and Gobiioides were some identified fish groups found in the stomach of $L$. calcarifer. The next major food groups were macro-crustaceans (26.32\%), followed by zooplankton (19.91\%), insect (9.02\%) and algae (7.69\%). The major zooplanktons were Euglena, cladocerans (Daphnia and some others), copepodes (calanoides), shrimp larvae, megalopa larvae of crabs. Among the identified algae in the stomach of $L$. calcarifer, Coscinodiscus and Bacillariophyceae were common. The common macro-crustacean food items of $L$. calcarifer are decapods (shrimps and crabs), stomatopods and branchiurans.

The highest and lowest percentages of different food items found in the stomach of $L$. calcerifer are shown in Table 1. The highest numbers of full stomachs (richly fed and moderately fed) were found in the premonsoon and monsoon period (June to August), the highest number of empty stomachs (vacuum and poorly fed) were found in post monsoon period (December and January). From the study, it is also observed that the percentage of stomach fullness was higher in summer than the percentage in winter in juvenile $L$. calcarifer because both the growth and metabolism rate are positively related to the increasing temperature. Full stomachs were commonly occurred from May to July. $3 / 4$ full stomachs were mostly observed in March and April. $1 / 2$ full stomachs were found in most sampled Lates calcarifer in July and August, where $1 / 3$ full stomachs were found in November. $1 / 4$ full stomachs were available in L. calcarifer averagely almost in every month except June and July, where $1 / 8$ full stomachs were found only during October-April. From the acquired data, it is concluded that empty stomachs were rarely observed in $L$. calcarifer. 
Table 1. Monthly variation in the percentage occurrence of various groups of food items in the stomachs of juvenile $L$. calcarifer during the study period ( $n=65$ in each month, total of 680 specimens).

\begin{tabular}{|c|c|c|c|c|c|c|c|}
\hline \multirow{2}{*}{\multicolumn{2}{|c|}{$\begin{array}{l}\text { Year and } \\
\text { months }\end{array}$}} & \multicolumn{6}{|c|}{ Percentage of food items } \\
\hline & & \multirow{2}{*}{$\begin{array}{r}\text { Algae } \\
4.50\end{array}$} & \multirow{2}{*}{$\begin{array}{c}\text { Zooplankton } \\
21.80\end{array}$} & \multirow{2}{*}{$\begin{array}{c}\text { Macro-crustacean } \\
22.50\end{array}$} & \multirow{2}{*}{$\begin{array}{c}\text { Insects } \\
11.25\end{array}$} & \multirow{2}{*}{$\begin{array}{c}\text { Teleostei } \\
36.50\end{array}$} & \multirow{2}{*}{$\begin{array}{c}\text { Unidentified } \\
3.45\end{array}$} \\
\hline \multirow{6}{*}{2010} & July & & & & & & \\
\hline & August & 9.25 & 25.00 & 17.50 & 09.50 & 35.50 & 3.25 \\
\hline & September & 9.50 & 19.10 & 30.25 & 10.25 & 28.75 & 2.15 \\
\hline & October & 6.50 & 15.30 & 36.00 & 08.00 & 30.70 & 3.50 \\
\hline & November & 6.50 & 14.30 & 28.00 & 06.50 & 40.45 & 4.25 \\
\hline & December & 5.90 & 13.50 & 34.50 & 06.25 & 35.50 & 4.35 \\
\hline \multirow{6}{*}{2011} & January & 8.60 & 17.80 & 30.60 & 08.50 & 30.40 & 4.10 \\
\hline & February & 5.50 & 17.90 & 23.50 & 12.00 & 37.20 & 3.90 \\
\hline & March & 12.00 & 19.70 & 26.80 & 07.50 & 31.20 & 2.80 \\
\hline & April & 6.25 & 23.40 & 24.50 & 09.50 & 32.90 & 3.45 \\
\hline & May & 7.90 & 24.90 & 22.20 & 10.25 & 31.80 & 2.95 \\
\hline & June & 9.90 & 26.25 & 19.50 & 08.75 & 33.50 & 2.10 \\
\hline
\end{tabular}

The ratio of the total length $(T L)$ and alimentary canal length $(A C L)$ of different size group of the juvenile $L$. calcarifer is shown in Table 2. Positive linear relationship was observed in maximum cases between body length and alimentary canal length and the relationship of the total length with alimentary canal length of the fish was established as ACL $=0.642 \mathrm{TL}-0.354$, where $\mathrm{r}^{2}=0.992$.

Table 2. Relationship between total length (TL) and alimentary canal length $(A C L)$ in different size groups of juvenile Lates calcarifer $(\mathrm{n}=280)$.

\begin{tabular}{|c|c|c|c|c|c|c|c|c|c|c|}
\hline \multirow{2}{*}{$\begin{array}{l}\text { Size } \\
\text { group } \\
\text { (cm) }\end{array}$} & \multirow{2}{*}{$\begin{array}{l}\text { No. of } \\
\text { sample }\end{array}$} & \multicolumn{2}{|c|}{$\mathrm{TL}(\mathrm{cm})$} & \multicolumn{2}{|c|}{$\mathrm{ACL}(\mathrm{cm})$} & \multirow{2}{*}{$\begin{array}{l}\text { Mean ratio } \\
\text { (TL:ACL) }\end{array}$} & \multirow[t]{2}{*}{ Formula } & \multirow{2}{*}{$\begin{array}{l}\text { Value } \\
\text { of } a\end{array}$} & \multirow{2}{*}{$\begin{array}{l}\text { Value } \\
\text { of } b\end{array}$} & \multirow{2}{*}{$\begin{array}{l}\text { Value } \\
\text { of } r^{2}\end{array}$} \\
\hline & & Mean & SD & Mean & SD & & & & & \\
\hline $\begin{array}{l}15.00- \\
17.50\end{array}$ & $n=88$ & 15.99 & 0.78 & 10.05 & 0.42 & $1: 0.63$ & \multirow{4}{*}{$\begin{array}{c}\mathrm{ACL}=0.642 \\
\mathrm{TL}-0.354\end{array}$} & \multirow{4}{*}{-0.354} & \multirow{4}{*}{0.642} & \multirow{4}{*}{0.992} \\
\hline $\begin{array}{l}17.50- \\
20.00\end{array}$ & $n=72$ & 18.65 & 0.62 & 11.43 & 0.40 & 1:0.61 & & & & \\
\hline $\begin{array}{l}20.00- \\
22.50\end{array}$ & $n=66$ & 21.81 & 0.62 & 13.66 & 0.62 & 1:0.63 & & & & \\
\hline $\begin{array}{l}22.50- \\
25.00\end{array}$ & $n=54$ & 23.89 & 0.75 & 15.06 & 0.46 & $1: 0.67$ & & & & \\
\hline
\end{tabular}




\section{References}

Allen GR, Midgley SH, Allen M. 2002. Field guide to the freshwater fishes of Australia. Western Australian Museum, Perth, Western Australia. $394 \mathrm{p}$.

Bianchi G. 1985. FAO species identification sheets for fishery purposes. Field guide to the commercial marine and brackish-water species of Pakistan. Prepared with the support of PAK/77/033 and FAO (FIRM) Regular Programme. Rome: FAO. 200 p.

Bowen SH.1985. Quantitative description of the diet. Nielson LA, Johnson DL and Lampton S (Eds.). Blacksburg fisheries Techniques. pp. 325-336.

Cheung WWL, Pitcher TJ, Pauly D. 2005. A fuzzy logic expert system to estimate intrinsic extinction vulnerability of marine fishes to fishing. Biol Conserv 124, 97-111. http://dx.doi.org/10.1016/j.biocon.2005.01.017

Davis T. 1985. The food of barramundi, Lates calcarifer (Bloch), in coastal and inland waters of Van Diemen Gulf and the Gulf of Carpentaria, Australia. Journal of fish biology 26(6), 669-682. http://dx.doi.org/10.1111/j.10958649.1985.tb04307.x

De GK. 1971. On the biology of post larvae and juvenile stages of Lates calcarifer (Bloch). J Indian Fish Assoc 1 (2), 51-64.

Fischer W.1974. FAO species identification sheets for fishery purposes: Eastern Indian Ocean (Fishing Area 57) and Western Central Pacific (Fishing Area 71). FAO/UN, Rome. 1 and 111p.

Hynes HBN. 1950. The food of freshwater stickleback with a review of the methods used in studies of fishes. J Anim Ecol 19, 41-57. http://dx.doi.org/10.2307/1570

Kailasam M, Thirunavukkarasu AR, Abraham M, Chandra PK, Subburaj R. 2002. Influence of size variation and feeding on cannibalism of Asian sea bass Lates calcarifer (Bloch) during hatchery rearing. Indian J Fish 49(2), 107-111.

Kapoor D, Dayal R, Ponniah AG. 2002. Fish biodiversity of India. National Bureau of Fish Genetic Resources Lucknow, India. $775 \mathrm{p}$.

Kungvankij P, Pudadera BJ, Tiro JRLB, Potestas IO. 1986. Biology and culture of sea bass (Lates calcarifer), NACA training manual series No. 3, Bangkok, Thailand. 70 pp.

Luna S. 2008. "Lates calcarifer, Barramundi: fisheries, aquaculture, gamefish, aquarium:" FishBase. Available at: http:/l fishbase. sinica.edu.tw/summary/speciessummary.php? genusname= Lates\&speciesname= calcarifer. Accessed 2 April, 2008.

Needham JG, Needham PR. 1962. Guide to the Study of Freshwater Biology. 5th ed. Holden day Inc. San Francisco. $108 \mathrm{pp}$.

Patnaik S, Jena S. 2011. Some aspects of biology of Lates calcerifer (Bloch) from Chilka Lake. Chilka Investigation Unit of the Central Inland Fisheries Research Institute, Balugaon, Orissa, India. 65-71.

Pethiyagoda R. 1991. Freshwater fishes of Sri Lanka. The Wildlife Heritage Trust of Sri Lanka, Colombo. 362 p.

Rahman AKA.1989. Freshwater Fishes of Bangladesh, 1st ed. Zoological Society of Bangladesh, Department of Zoology, University of Dhaka, Dhaka -1000. 337pp.

Tacon AGJ. Rausin N, Kadari M, Cornelis P. 1991. The food and feeding of tropical marine fishes in floating net cages: Asian seabass, Lates calcarifer (Bloch), and brown-spotted grouper, Epinephelus tauvina (Forskal), Aquaculture and Fisheries Management 22, 165-182.

Todd CD, Levarak MS. 1991.Coastal marine zooplankton: A practical manual for students. Cambridge University press, Cambridge. $106 \mathrm{pp}$.

Yadav BN. 1999. Fish and fisheries, Daya Publishing House, New Delhi, India. 366 pp. 